\title{
The protection of the bat community in the Dupnisa Cave System, Turkey, following opening for tourism
}

\author{
SERBÜLENT PaKsuZ and BeYtullah ÖZKan
}

\begin{abstract}
The aim of this study was to protect the bat community and roosting sites in the Dupnisa Cave System in the Yildiz (Istranca) Mountains in Thrace, the European part of Turkey, following the opening of the caves to tourism. We investigated the seasonal population dynamics and use of the cave system by bats, carrying out 15 surveys before (2002-2003) and 38 surveys after (2004-2008) the cave system was opened to tourism. We recorded 15 species of bats; the highest numbers recorded in a single survey were 54,600 hibernating and 11,000 breeding/nursing. Different parts of the cave system are used by bats to various degrees according to season. To protect the bats and the cave system the visitor schedule took into consideration the differences in seasonal use of the caves by bats. There was a significant increase in the total number of bats recorded in the cave system after opening for tourism, possibly because the gating of two entrances helped to control visitation. The results of our surveys of this cave system show that gating of entrances and visits by tourists are not necessarily incompatible with the use of caves by bats for both hibernating and nursing. Understanding how the three caves are used seasonally by the bat community, and for what purposes (hibernation vs nursing), was critical for the establishment of an appropriate management plan for tourism.
\end{abstract}

Keywords Bat populations, cave gates, Dupnisa Cave System, tourism activities, Turkey, visitor schedule

\section{Introduction}

Tncreasing urbanization is having negative impacts on bats 1 and their key roosting sites. Natural bat roosting sites are uncommon but increases in ecotourism have damaged or destroyed such sites, and in some cases populations of bats have been extirpated (Beshkov, 1998; Furman \& Özgül, 2002, 2004; Mann et al., 2002; Albayrak, 2005; Pennisi et al., 2005; Rudolph et al., 2005; Niu et al., 2007; Papadatou et al.,

SERBÜLENT PAKSUZ (Corresponding author) Department of Elementary Teaching, Faculty of Education, Trakya University, 22030 Edirne, Turkey. E-mail serpaksuz@trakya.edu.tr

Beytullah ÖZkan Department of Biology, Faculty of Science, Trakya University, 22030 Edirne, Turkey

Received 13 May 2010. Revision requested 28 June 2010.

Accepted 24 August 2010. First published online 9 January 2012.
2009). Natural caves and artificial underground sites are widely used as roosting sites by bats and may be occupied by large breeding and/or hibernating populations (Altringham, 1996). Disturbance by visitors to caves is a widespread problem and has been documented as a major threat to cave-dwelling bats (Barbour \& Davis, 1969; Humphrey \& Kunz, 1976; Tuttle, 1979; Thomas et al., 1990; Speakman et al., 1992; Wegiel \& Wegiel, 1998; Martin et al., 2003; Pennisi et al., 2005). Disturbances of bat roosts can result in the abandonment of hibernation and maternity caves (White \& Seginak, 1987; Tuttle \& Taylor, 1998; Ludlow \& Gore, 2000; Thomson, 2002).

Contemporary efforts for bat conservation focus on protecting caves and the various types of bat colonies they house (American Society of Mammalogists, 1992). Construction of gates at the entrances of caves is a typical method of protection for important bat roosts (Tuttle, 1977; Humphrey, 1978; Tuttle \& Stevenson, 1978). Of all the full closure structures, gates with horizontal bars are the most commonly used. Given the paucity of published data on the effects of gates, bat activity needs to be carefully monitored before and after the placement of a gate (Pugh \& Altringham, 2005). In addition, illumination (Mann et al., 2002) and landscaping in caves visited by tourists can negatively affect the behaviour of bats. Besides appropriate gate construction, a suitable visitor schedule and a management plan are therefore necessary to protect bats and their roots in such caves.

The distribution and availability of suitable roosting sites is a limited resource for some cave-dwelling bat species (Humphrey, 1975). The often specialized physiological roosting requirements of bats dictate the environments in which a species can or cannot successfully roost. The Dupnisa Cave System is one of the largest winter and summer bat roosts in south-east Europe and the most important site for bats in the Thrace region of Turkey (Furman \& Özgül, 2004; Paksuz, 2004; Paksuz et al., 2007). The popularity of this cave system with tourists and speleologists previously posed a serious threat to the bats that roost there.

The effects of human activities on the bat community in a region can be assessed only by continuous monitoring. Because roosts with different functions are needed to complete the annual life cycle of a species, protecting only those sites with large numbers of bats may be insufficient: management for conservation requires a comprehensive understanding of roosting ecology (Kurta \& Kennedy, 2002). The aim of this study was therefore to determine 


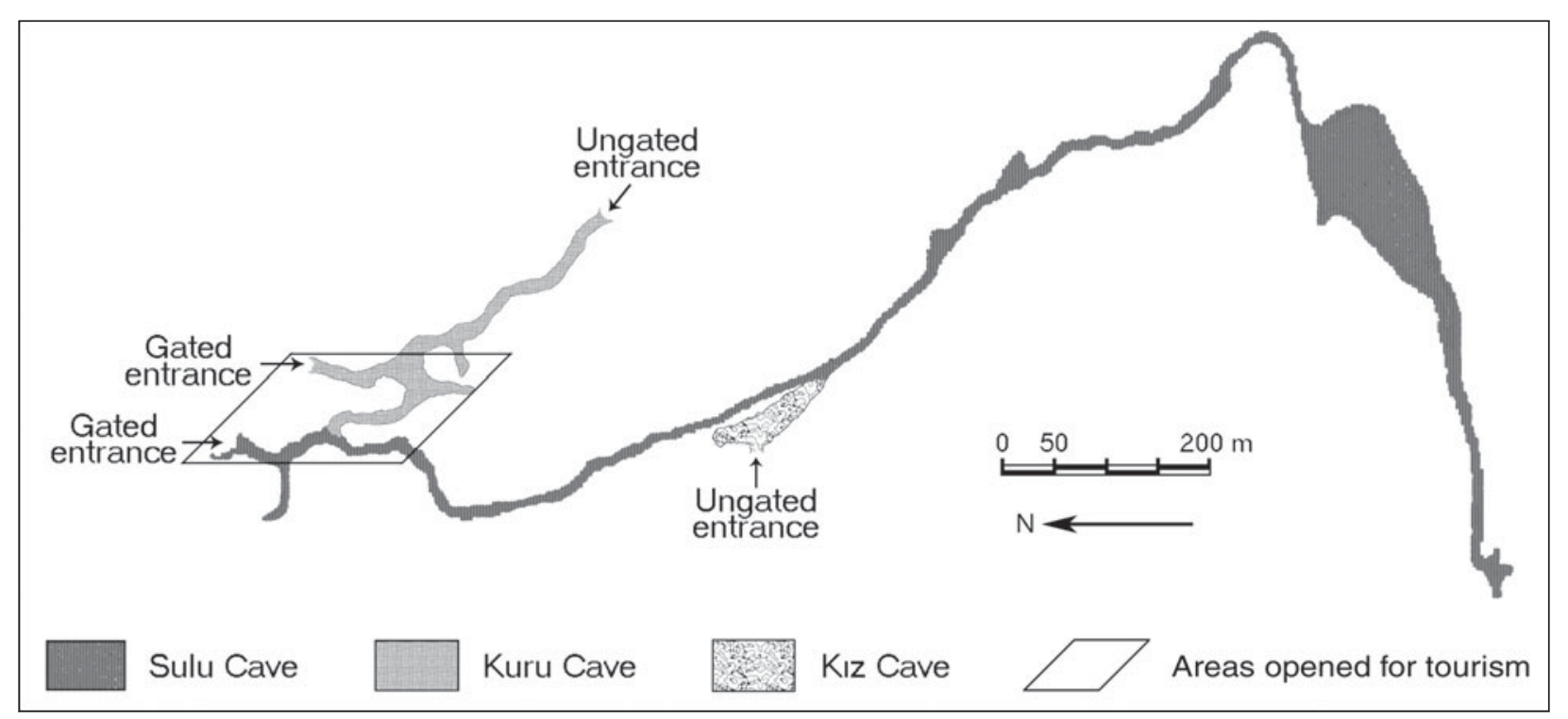

FIG. 1 The Dupnisa Cave System, showing the location of the three main caves, the areas open to tourists, and the gated and ungated entrances (Plate 1). Adapted from Nazik et al. (1998).

seasonal numbers and roost use by bats in the Dupnisa Cave System before and after it was opened to tourism and to develop a management plan for protection of the bat species using the cave system. We also evaluated the effects of tourism and gates on the bats.

\section{Study area}

The Dupnisa Cave System lies south of Kırklareli-Sarpdere Village in the forested Ylldiz (Istranca) Mountains in Thrace, the European part of Turkey. At 2,720 m long this cave system is the second longest in Thrace and is regarded as a cave system because it includes two floors and three connected caves (Fig. 1). The process of formation and development of this cave system continues. The main gallery, through which an underground stream flows, is Sulu Cave (1,977 m long). Formation of the two caves above the main gallery (Kuru Cave, $480 \mathrm{~m}$; Kız Cave, $263 \mathrm{~m}$ ) is complete (Nazik et al., 1998).

This is the first cave system in Turkey to open with a visitor schedule and a gate construction based on the seasonal use of the cave system by bats, and long-term monitoring is conducted. The cave system has been visited by nearly 21,000 visitors each year since it was opened to tourism in July 2003; most of the visits occur from late May to July. Tourist circuits have been constructed in the first $200 \mathrm{~m}$ of the Sulu Cave and the first $230 \mathrm{~m}$ of the Kuru Cave but the Kız Cave is closed to tourism (Fig. 1). The cave system has four entrances. We gated the two entrances to the tourist circuits before the system was opened to tourism. The gates were constructed with horizontal iron bars that have a 200-mm spacing (Plate 1). The other entrances of the cave system, which are located away from
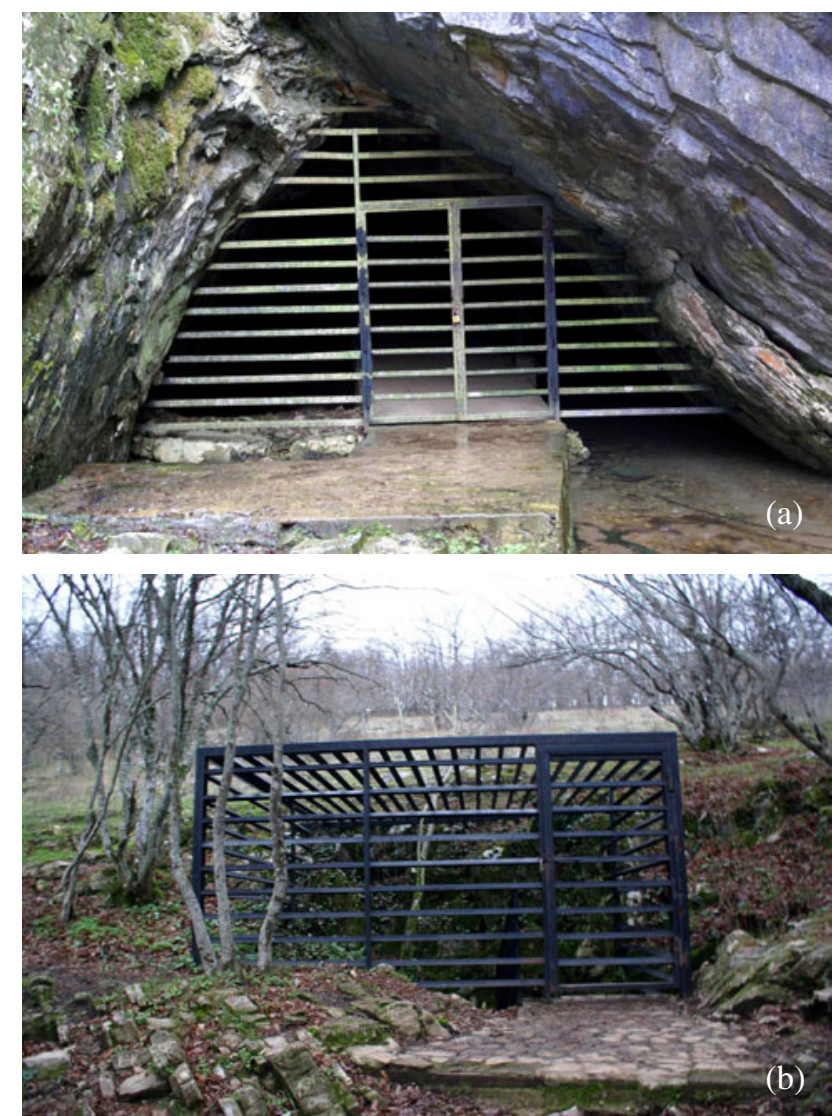

Plate 1 The gated entrances to (a) Sulu Cave and (b) Kuru Cave, used to control the entry of tourists. The horizontal bars have a spacing of $200 \mathrm{~mm}$ to allow bats to move freely.

the area opened to tourism, are difficult to access and remain ungated to minimize the negative effects of the two gates on the bats. 


\section{Methods}

We carried out 15 surveys before (2002-2003) and 38 surveys after (2004-2008) the cave system was opened to tourism. Surveys were conducted approximately once every 40 days for 1-2 days, during daytime, when the bats were in their roosts. In each survey we recorded the population sizes and use of roosts by each bat species in the three parts of the cave system. We could not survey in some months because of bad weather and various other unanticipated circumstances. Bats were identified visually with reference to Dietz \& Von Helversen (2004); when necessary we collected bats with a net mounted on an extendable rod and released them after identification.

Isolated individuals and small colonies were counted directly. The sizes of larger colonies were estimated by counting bats in an area of $30 \times 30$ or $50 \times 50 \mathrm{~cm}$ and multiplying the number in the area counted by the total area of the colony. For some colonies we repeated the count several times and estimated that our margin of error was c. $10 \%$. The spatial distribution of the bats was quantified using Green's index $\left(C_{x}\right.$; Green, 1966), which varies between $o$ (for a random distribution) and 1 (for a clumped distribution). Differences between the total population sizes of bat species in the different parts of the cave system in different seasons were examined by independent sample $t$-tests. Wilcoxon matched-pair signed ranks tests were used to test for differences between the population sizes in the various parts of the cave system before and after installation of gates and opening for tourism. Correlations between the seasonal use of the various parts of the cave system before and after the opening of tourism were compared with Spearman's rank correlation coefficient test. Total numbers and roost use were investigated in the winter/hibernation period (November-March) and summer/nursery period (April-October).

\section{Results}

We found 15 bat species in the cave system: Rhinolophus ferrumequinum, Rhinolophus hipposideros, Rhinolophus euryale, Rhinolophus mehelyi, Rhinolophus blasii, Myotis myotis, Myotis blythii, Myotis bechsteinii, Myotis nattereri, Myotis emarginatus, Myotis mystacinus, Myotis daubentonii, Myotis capaccinii, Plecotus auritus and Miniopterus schreibersii. The maximum numbers of bats recorded was 54,600 hibernating in January 2004 and 11,00o breeding/ nursing in August 2006. The three parts of the cave system were used by different species to varying degrees, according to season.

Sulu Cave was used for hibernation by nine species: R. ferrumequinum, M. myotis, M. blythii, M. emarginatus, M. mystacinus, M. nattereri, M. capaccinii, M. daubentonii and M. schreibersii. The cave was used only for seasonal movements during the summer and not for breeding/ nursing. These nine species comprised, overall, $73 \%$ of the total number of bats recorded in the cave system during the study. The most numerous species recorded in the cave in a single survey were $M$. schreibersii (36,000 individuals), M. blythii (4,000), R. ferrumequinum (2,200) and M. capaccinii $(1,800)$. The highest number of bats recorded in this cave was 44,500 hibernating individuals in January 2004 (Table 1).

Kuru Cave was used by 10 species ( $R$. ferrumequinum, $R$. hipposideros, $R$. euryale, $R$. mehelyi, M. myotis, M. blythii, M. bechsteinii, M. capaccinii, M. schreibersii and P. auritus) that, overall, comprised $7 \%$ of the total number of bats recorded in the cave system. The cave was used by bats throughout the year, with the majority of the bat assemblages being for breeding and nursing in the summer. The most numerous species in the cave in a single survey were $R$. euryale (2,500), M. schreibersii (2,400), M. blythii (1,200) and R. ferrumequinum (90o). The maximum number of bats recorded in the cave was 6,800 breeding and nursing individuals in August 2003 (Table 1).

$\mathrm{K} 1 \mathrm{z}$ Cave was used by seven species for hibernating and breeding/nursing throughout the whole year ( $R$. ferrumequinum, R. euryale, R. mehelyi, R. blasii, M. myotis, M. blythii and M. schreibersii) that, overall, comprised $20 \%$ of the total number of bats recorded in the cave system. The most numerous species in the cave in a single survey were $M$. schreibersii (9,500), R. euryale (1,600), R. ferrumequinum (300) and $R$. mehelyi (300). The maximum number of bats counted was 10,100 hibernating individuals in January 2004 (Table 1).

Overall, significantly more bats were recorded in the winter than in the summer (Table 2), and the bat colonies were noticeably clustered for hibernation in the winter but less so for breeding/nursing in the summer. The differences in numbers between seasons were significant in Sulu Cave and Kiz Cave but not in Kuru Cave (Table 2). The spatial distribution of bats in the cave system was random in both seasons $\left(C_{x}=0.09\right.$ and $C_{x}=0.03$ in winter and summer, respectively). The spatial distribution of bats in Sulu Cave was close to random in the winter $\left(C_{x}=0.10\right)$ but more clumped in the summer $\left(C_{x}=0.72\right)$. In Kuru and Kiz Caves bats were randomly distributed in both winter and summer (Kuru: $C_{x}=0.06$ and $C_{x}=0.15$, respectively; K1z: $C_{x}=0.06$ and $C_{x}=0.01$, respectively). The highest numbers of bats recorded in the cave system in any single survey before and after the system opened to tourism were 42,800 and 54,600 hibernating, respectively, and 7,900 and 11,00o breeding/ nursing, respectively. The total number of bats in the cave system was significantly lower before (2002-2003) compared to after (2004-2008) the opening for tourism $(z=-2.353, \mathrm{P}<0.05)$. The total number of bats in Sulu 
TABLE 1 Monthly numbers of bats (all 17 species combined) before (2002-2003) and after (2004-2008) tourism activities commenced in the Dupnisa Cave System (Fig. 1). A blank cell indicates the absence of a survey in that month and year.

\begin{tabular}{|c|c|c|c|c|c|c|c|}
\hline Month & 2002 & 2003 & 2004 & 2005 & 2006 & 2007 & 2008 \\
\hline \multicolumn{8}{|c|}{ Sulu Cave } \\
\hline Jan. & & 33,257 & 44,477 & & & 37,034 & 41,108 \\
\hline Feb. & & 26,326 & 28,422 & 21,632 & 20,210 & & 19,821 \\
\hline Mar. & & 5,921 & 12,450 & & & 14,802 & 8,734 \\
\hline Apr. & 4,395 & 1,674 & 3,045 & & & 2,204 & \\
\hline May & 165 & 17 & 324 & & 142 & & \\
\hline June & 3 & o & o & & 5 & & 1 \\
\hline July & o & o & 4 & 2 & o & & 2 \\
\hline Aug. & 23 & o & 16 & 43 & 12 & & \\
\hline Sep. & 49 & 74 & & 116 & & 93 & \\
\hline Oct. & 165 & & & 137 & 184 & & 124 \\
\hline Nov. & 604 & 936 & & & 2,016 & 4,302 & \\
\hline Dec. & 19,840 & 22,146 & & 27,562 & & 23,920 & \\
\hline \multicolumn{8}{|c|}{ Kuru Cave } \\
\hline Jan. & & 6 & 53 & & & 46 & 37 \\
\hline Feb. & & 17 & 111 & 78 & 54 & & 92 \\
\hline Mar. & & 18 & 132 & & & 124 & 182 \\
\hline Apr. & 81 & 76 & 201 & & & 163 & \\
\hline May & 78 & 64 & 85 & & 126 & & \\
\hline June & 191 & 164 & 207 & & 342 & & 208 \\
\hline July & 5,409 & 4,662 & 6,320 & 2,739 & 5,610 & & 6,020 \\
\hline Aug. & 3,445 & 6,778 & 3,985 & 1,706 & 6,026 & & \\
\hline Sep. & 1,336 & 2,581 & & 2,816 & 1,862 & 3,728 & \\
\hline Oct. & 1,668 & & & 1,028 & & & 1,864 \\
\hline Nov. & 68 & 9 & & & 79 & 46 & \\
\hline Dec. & 23 & 14 & & 17 & & 12 & \\
\hline \multicolumn{8}{|c|}{ Kiz Cave } \\
\hline Jan. & & 9,556 & 10,130 & & & 8,603 & 8,783 \\
\hline Feb. & & 3,538 & 6,948 & 3,017 & 6,134 & & 5,236 \\
\hline Mar. & & 1,914 & 2,024 & & & 3,683 & 1,927 \\
\hline Apr. & 1,126 & 841 & 509 & & & 643 & \\
\hline May & 966 & 328 & 2,137 & & 2,840 & & \\
\hline June & 1,010 & 1,850 & 1,915 & & 1,634 & & 2,612 \\
\hline July & 1,355 & 878 & 1,620 & 2,406 & 1,970 & & 2,235 \\
\hline Aug. & 1,125 & 1,020 & 1,812 & 1,204 & 4,986 & & \\
\hline Sep. & 870 & 904 & & 1,802 & 2,232 & 3,802 & \\
\hline Oct. & 2,387 & & & 3,020 & & & 2,861 \\
\hline Nov. & 2,338 & 2,630 & & & 2,958 & 2,734 & \\
\hline
\end{tabular}

Cave $(z=-1.255, \mathrm{P}>0.05)$ and Kuru Cave $(z=-1.334$, $\mathrm{P}>0.05)$ were not significantly different before and after opening to tourism but the difference was significant for K1z Cave $(z=-2.118, \mathrm{P}<0.05)$. The correlations between the different parts of the cave system before $\left(r_{\mathrm{s}: s u l u / k u r u}=-0.90, \quad \mathrm{P}<0.001 ; \quad r_{\mathrm{s}: \text { sulu } / \mathrm{kiz}}=0.67, \mathrm{P}<0.05 ;\right.$ $\left.r_{\mathrm{s}: \mathrm{kuru} / \mathrm{kzz}}=-0.58, \mathrm{P}<0.05\right)$ and after $\left(r_{\mathrm{s}: \text { sulu } / \mathrm{kuru}}=-0.86\right.$, $\mathrm{P}<0.001 ; \quad r_{\mathrm{s}: \mathrm{sulu} / \mathrm{klz}}=0.69, \quad \mathrm{P}<0.05 ; \quad r_{\mathrm{s}: \mathrm{kuru} / \mathrm{kzz}}=-0.64$, $\mathrm{P}<0.05)$ opening to tourism were all significant. The correlations between the Sulu/Kuru and the Kuru/Kız Caves were negative but positive between the Sulu/Kız Caves. The directions of these correlations were the same before and after opening for tourism.

\section{Discussion}

A comparison of our results with previous studies (Albayrak, 1993; Benda \& Horacek, 1998; Furman \& Özgül, 2004; Paksuz, 2004; Paksuz et al., 2007) shows that a total of 17 species of bats have been recorded in the Dupnisa Cave System. The two species that we did not record are Barbastella barbastellus and Plecotus austriacus (Benda \& Horacek, 1998; Furman \& Özgül, 2004). These 17 species comprise $45 \%$ of the 38 bat species known from Turkey and therefore this cave system is of national importance for bat conservation. Five of the species are categorized on the IUCN Red List (IUCN, 2010): R. mehelyi and M. capaccinii 
TABLE 2 The mean numbers of bats in the winter (NovemberMarch) and summer (April-October) in the three parts of the Dupnisa Cave System (Fig. 1), and statistical comparison with an independent samples $t$-test.

\begin{tabular}{lcccc}
\hline Cave \& season & Mean \pm SD $(\%)$ & $t$ & df & P \\
\hline Sulu cave & & & & \\
Winter & $19,612 \pm 14,117(97)$ & -3.648 & 10 & 0.004 \\
Summer & $464 \pm 1,045(3)$ & & & \\
Kuru cave & & & & \\
Winter & $50 \pm 29(2)$ & 2.046 & 10 & 0.068 \\
Summer & $1,991 \pm 2,091(98)$ & & & \\
Kiz cave & & & & \\
Winter & $4,925 \pm 2,765(66)$ & -2.953 & 10 & 0.014 \\
Summer & $1,800 \pm 589(34)$ & & & \\
Total & & & & \\
Winter & $24,623 \pm 16,707(80)$ & -3.259 & 10 & 0.009 \\
Summer & $4,256 \pm 1,952(20)$ & & & \\
\hline
\end{tabular}

as Vulnerable, and $R$. euryale, M. bechsteinii and M. schreibersii as Near Threatened.

The protection of roosting sites is an essential component of any strategy for the conservation of bats. A study of the effect of cave tours on a maternity colony of bats found them to be negatively affected by light and noise (Mann et al., 2002). Illumination located in caves for a long time causes changes in the formation of a cave and in its ecosystem. In Greece (Paragamian et al., 2004; Papadatou et al., 2009), Bulgaria (Beshkov, 1998) and Turkey (Özgül et al., 2000; Furman \& Özgül, 2002, 2004; Albayrak, 2005) suitable underground areas have deteriorated and cavedwelling bat populations have declined because of such effects. Many caves in Turkey and Bulgaria (Petrov, 2008) that were opened to tourism were closed with gates that did not allow bats to fly in or out, and in Turkey visitor schedules for caves opened for tourism have generally not taken into account the seasonal use of the caves by bats.

Based on the long-term monitoring data that we collected in the Dupnisa Cave System the visitor schedule was designed to take into account the seasonal use of the caves by bats, to minimize disturbance. Sulu Cave is closed to tourism between 15 November and 15 May because the cave is used by hibernating bats during these dates. Kuru Cave is open to visits during the whole year because roosting colonies are located away from the tourist circuit. Kiz Cave is closed to tourism because it is used for hibernating and breeding/nursing throughout the year. The entrances to the cave system for tourists were closed with horizontal angle iron gates to control human disturbance. Additional precautions were taken to protect the bats and the cave system: the time of visits has to be an hour after sunrise and an hour before sunset because of bat activity, visits are controlled by security guards all year and are only conducted in groups (with time limits and only on set routes), illumination inside the cave system is turned off when there are not any visitors and when it is not visiting time, and information notes about the bats and the cave system have been placed in suitable places at the entrances of the caves.

The distribution of bat species is significantly correlated with the type and size of cave. Large natural caves deserve special consideration for protection because of their high species richness and abundance (Niu et al., 2007). The three caves of the Dupnisa Cave System have a variety of microclimates and topography (Paksuz et al., 2007) and consequently host large, multi-species bat assemblages. During foraging and swarming bats fly in and out of a cave repeatedly, night after night (Thomas et al., 1979; Parsons et al., 2003; Rivers et al., 2006) and spacing of bars in any gate is critical. The recommended minimal horizontal bar spacing is $150 \mathrm{~mm}$ (Tuttle, 1977; Tuttle \& Taylor, 1998; Burghardt, 2000; Powers, 2002; Martin et al., 2003; Pugh \& Altringham, 2005; Slade \& Law, 2008). The bars in the two gates of the Dupnisa Cave System have gaps of $200 \mathrm{~mm}$ because of the large numbers of bats in the cave system. Ludlow \& Gore (2000) demonstrated that, when given a choice, bats use ungated entrances more than gated ones. The other entrances of the cave system, which are located away from the tourist circuits, were therefore left ungated to minimize the negative effects of the two gates. Gated cave entrances prevent human disturbance and can increase the protection of bat populations but their effects on bats have not been adequately assessed (Tuttle, 1977; Humphrey, 1978; Tuttle \& Stevenson, 1978; Richter et al., 1993; Martin et al., 2003).

In the Dupnisa Cave System the highest total number of bats previously recorded in a single survey was 33,000 , in the winter of 2001 (Furman \& Özgül, 2004) whereas in our study we recorded 42,800 individuals in January 2003 and 54,600 individuals in January 2004 (Table 1). The total number of bats in the cave system significantly increased after opening for tourism (2004-2008) compared to before (2002-2003). This increase was significant only in K1z Cave, which is closed to tourism and ungated. This increase may indicate that the bats prefer to use ungated entrances, as found by Ludlow \& Gore (2000).

Before the Dupnisa Cave System was open to tourism it had been visited frequently by cavers and treasure hunters. These uncontrolled visits probably disturbed the bats and the increase in the total number of bats following the opening for tourism may be related to the control of visits by the installation of gates and the visitor schedule.

The three parts of the Dupnisa Cave System were used by bats to varying degrees in winter and summer. Sulu Cave and $\mathrm{K} 1 \mathrm{z}$ Cave were used mainly by hibernating bats whereas Kuru Cave was mainly used as a nursery roost. The negative correlations between the Sulu/Kuru and the Kuru/Kız Caves 
indicated that when the number of bats in one cave increased it decreased in the other cave because of movements between the caves. However, the positive correlation between the Sulu/Krz Caves indicated that the numbers of bats in the caves increased and decreased in the same seasons. As these correlations in numbers of bats between the different parts of the cave system were preserved following gating and opening for tourism it indicates that the seasonal use of the cave system by bats were not affected by controlled visitation.

The results of our surveys of the Dupnisa Cave System show that gating of entrances and visits by tourists are not necessarily incompatible with the use of caves by bats for both hibernating and nursing. Understanding how the three caves are used seasonally by the bat community, and for what purposes (hibernation vs nursing), was critical for the establishment of an appropriate management plan for tourism.

The density and species richness of cave-dwelling bat communities depend on the presence of suitable types of caves and their microclimates, and roosting sites are limited and are therefore important for bat conservation. The Dupnisa Cave System may become more important for the cave-dwelling bats of southern Europe because the three caves have different microclimatic conditions and thus provide alternative microclimates in different seasons and caves. Studies need to be conducted on the behaviour of bats within this cave system and on the system's microclimate, which could potentially be modified by tourism activities, and the present monitoring needs to continue.

\section{Acknowledgements}

We thank Professor Cengiz Kurtonur and Dr Ebru Buruldağ for their help with this study, and Muharrem Obuz for accommodation and other assistance. This study was partially supported by the Kirklareli Governorship.

\section{References}

Albayrak, I. (1993) Batı Türkiye yarasaları ve yayılışları (Mammalia: Chiroptera). Doğa-Turkish Journal of Zoology, 17, 237-257.

Albay RaK, I. (2005) Türkiye'deki Mağara Yarasalarının Bazı Biyolojik Özellikleri. Ulusal Mağara Günleri Sempozyumu (ed. I. Albayrak), pp. 159-167. Türkiye Tabiatını Koruma Derneği, Beyşeir, Konya, Türkiye.

Altringham, J.D. (1996) Bats: Biology and Behaviour. Oxford University Press, Oxford, UK.

American Society of Mammalogists (1992) Guidelines for the protection of bat roosts. Journal of Mammalogy, 73, 707-710.

Barbour, R.W. \& Davis, W.H. (1969) Bats of America. University of Kentucky Press, Lexington, USA.

Benda, P. \& Horacek, I. (1998) Bats (Mammalia: Chiroptera) of the Eastern Mediterranean. Part 1. Review of distribution and taxonomy of bats in Turkey. Acta Societatis Zoologicae Bohemicae, 62, 255-313.

Beshkov, V. (1998) The bats in Bulgaria. In Bulgaria's Biological Diversity: Conservation Status and Needs Assessment (ed. C. Meine), pp. 453-466. Biodiversity Support Program, Washington, DC, USA.

Burghardt, J.E. (2000) Bat-compatible closures of abandoned underground mines in National Park system units. In Proceedings of Bat Conservation and Mining: A Technical Interactive Forum November 14-16 (eds K.C. Vories \& D. Throgmortan), pp. 79-98. U.S. Department of the Interior, Office of Surface Mining, Bat Conservation International, and Coal Research Center, Southern Illinois University at Carbondale, St. Louis, USA.

Dietz, C. \& Von Helversen, O. (2004) Identification Key to the Bats of Europe. Http://public.carnet.hr/speleo/znanost/sismisi/ Dietz_von_Helversen_2004IDkey_1.pdf and http://public.carnet.hr/ speleo/znanost/sismisi/Dietz_von_Helversen_2004IDkey_2.pdf [accessed 15 December 2004].

Furman, A. \& ÖZGÜL, A. (2002) The distribution of cave-dwelling bats and conservation status of underground habitats in Istanbul area. Ecological Research, 17, 69-77.

Furman, A. \& ÖzGÜL, A. (2004) The distribution of cave-dwelling bats and conservation status of underground habitats in northwestern Turkey. Biological Conservation, 120, 247-252.

Green, R.H. (1966) Measurement of non-randomness in spatial distributions. Researches on Population Ecology, 8, 1-7.

Humphrey, S.R. (1975) Nursery roosts and community diversity of Nearctic bats. Journal of Mammalogy, 56, 321-346.

Humphrey, S.R. (1978) Status, winter habitat and management of the endangered Indiana bat (Myotis sodalis). Florida Scientist, 41, $65-76$.

Humphrey, S.R. \& Kunz, T.H. (1976) Ecology of a Pleistocene relict, the western big-eared bat (Plecotus townsendii), in the southern Great Plains. Journal of Mammalogy, 57, 471-494.

IUCN (2010) IUCN Red List of Threatened Species v. 2010.2. IUCN, Gland, Switzerland. http://www.iucnredlist.org [accessed 25 July 2010].

Kurta, A. \& Kennedy, J. (2002) The Indiana Bat: Biology and Management of an Endangered Species. Bat Conservation International, Austin, USA.

Ludlow, M.E. \& Gore, J.A. (2000) Effects of a cave gate on emergence patterns of colonial bats. Wildlife Society Bulletin, 28, 191-196.

ManN, S.L., SteidL, R.J. \& Dalton, V.M. (2002) Effects of cave tours on breeding Myotis velifer. Journal of Wildlife Management, 66, 618624.

Martin, K.W., Leslie, Jr, D.M., Payton, M.E., Puckette, W.L. \& Hensley, S.L. (2003) Internal cave gating for protection of colonies of the endangered gray bat (Myotis grisescens). Acta Chiropterologica, 5, 143-150.

Nazik, L., Tork, K., Ozel, E., Mengi, H., Aksoy, B., Derici, S. \& Kutlay, H. (1998) Dupnisa Mağara Sistemi (Demirköy-Kırklareli) araştırma raporu. Mimari ve elektrifikasyon uygulama projesi. MTA raporu, Derleme no: 10089, Ankara, Turkey.

Niv, H., Wang, N., ZhoA, L. \& LiU, J. (2007) Distribution and underground habitats of cave-dwelling bats in China. Animal Conservation, 10, 470-477.

ÖzGül, A., Bilgin, R. \& Furman, A. (2000) Cave-dwelling bats (Mammalia: Chiroptera) of Çatalca-Kocaeli region, north-western Turkey. In Proceedings of the VIIIth European Bat Research Symposium (ed. B.W. Woloszyn), pp. 191-198. Chiropterological Information Center, Krakow, Poland.

PAKsuz, S. (2004) Bats of Dupnisa Cave System (Mammalia: Chiroptera). MSc thesis, Trakya University, Edirne, Turkey.

Paksuz, S., Özkan, B. \& Postawa, T. (2007) Seasonal changes of cave-dwelling bat fauna, and their relationship with microclimate in 
Dupnisa Cave System (Turkish Thrace). Acta Zoologica Cracoviensia, 50A(1-2), 57-66.

Papadatou, E., Butlin, R.K., Pradel, R. \& Altringham, J.D. (2009) Sex-specific roost movements and population dynamics of the vulnerable long-fingered bat, Myotis capaccinii. Biological Conservation, 142, 280-289.

Paragamian, K., Nikoloudakis, E., Papadatou, E. \& SFAKIANAKI, E. (2004) Biological-Environmental Study of Maronia Cave: Analysis of Current Status-Proposals. Greek Institute of Speleological Research, Iraklion, Greece.

Parsons, K.N., Jones, G., Davidson-Watts, I. \& Greenaway, F. (2003) Swarming of bats at underground sites in Britainimplications for conservation. Biological Conservation, 111, 63-70.

Pennisi, L.A., Holland, S.M. \& S Tein, T.V. (2005) Achieving bat conservation through tourism. Journal of Ecotourism, 3, 195-207.

Petrov, B. (2008) Bats-Methodology for Environmental Impact Assessment and Appropriate Assessment. A Manual for Developers, Environmental Experts and Planning Authorities. National Museum of Natural History-Bulgarian Academy of Sciences, Sofia, Bulgaria.

Powers, JR, R.D. (2002) The angle iron gate. Bat gate design: a technical interactive forum. In Proceedings of Bat Conservation and Mining: A Technical Interactive Forum March 4-6 (eds K.C. Vories, D. Throgmortan \& A. Harrington), pp. 159-167. U.S. Department of the Interior, Office of Surface Mining, Bat Conservation International, and Coal Research Center, Southern Illinois University at Carbondale, Austin, USA.

Pugh, M. \& Altringham, J.D. (2005) The effect of gates on cave entry by swarming bats. Acta Chiropterologica, 7, 293-299.

Richter, A.R., Humphrey, S.R., Cope, J.B. \& Brack, Jr, V. (1993) Modified cave entrances: thermal effect on body mass and resulting decline of endangered Indiana bats (Myotis sodalis). Conservation Biology, 7, 407-415.

Rivers, N.M., Butlin, R.K. \& Altringham, J.D. (2006) Autumn swarming behaviour of Natterer's bats in the UK: population size, catchment area and dispersal. Biological Conservation, 172, 215-226.

Rudolph, B.U., Liegl, A. \& Karataş, A. (2005) The bat fauna of the caves near Havran in Western Turkey and their importance for bat conservation. Zoology in the Middle East, 36, 11-20.

Slade, C.P. \& Law, B.S. (2008) An experimental test of gating derelict mines to conserve bat roost habitat in south-eastern Australia. Acta Chiropterologica, 10, 367-376.

Speakman, J.R., Bullock, D.J., Eales, L.A. \& Racey, P.A. (1992) A problem defining temporal pattern in animal behaviour: clustering in the emergence behaviour of bats from maternity roosts. Animal Behaviour, 43, 491-500.

Thomas, D.W., Dorais, M. \& Bergeron, J.M. (1990) Winter energy budgets and cost of arousals for hibernating little brown bats, Myotis lucifugus. Journal of Mammalogy, 71, 475-479.

Thomas, D.W., Fenton, M.B. \& Barclay, R.M.R. (1979) Social behaviour of the little brown bat, Myotis lucifugus I. Mating behaviour. Behavioural Ecology and Sociobiology, 6, 129-136.

Thomson, B. (2002) Australian Handbook for the Conservation of Bats in Mines and Artificial Cave Bat Habitats. Australian Centre for Mining Environmental Research, Kenmore, Australia.

Tuttle, M.D. (1977) Gating as a means of protecting cave-dwelling bats. In Proceedings of the National Cave Management Symposium (eds T. Aley \& D. Rhodes), pp. 77-82. Speleobooks, Albuquerque, USA.

Tuttle, M.D. (1979) Status, causes of decline, and management of endangered gray bats. Journal of Wildlife Management, 43, 1-17.

Tuttle, M.D. \& Stevenson, D.E. (1978) Variation in the cave environment and its biological implications. In Proceedings of the National Cave Management Symposium (eds R. Zuber, J. Chester, S. Gilbert \& D. Rhodes), pp. 108-120. Speleobooks, Albuquerque, USA.

Tuttle, M.D. \& Taylor, D.A.R. (1998) Bats and Mines. Resource Publication No. 3-Revised. Bat Conservation International, Austin, USA.

Wegiel, A. \& Wegiel, J. (1998) Bat protection in caves in Poland. Myotis, 36, 63-69.

White, D.H. \& Seginak, J.T. (1987) Cave gate designs for use in protecting endangered bats. Wildlife Society Bulletin, 15, 445-449.

\section{Biographical sketches}

SERBÜLENT PAKSUZ studies the population and conservation ecology of bats. He specializes in cave-dwelling bats and carries out research on seasonal population dynamics and roost selection. He is currently studying the impacts of human activities on bat colonies in caves open to tourism and is developing management plans for protection of bat communities in caves. He is also interested in the species diversity and distribution of mammals in Turkey. Beytullah ÖzKan has conducted ecological and taxonomic studies on mammals for more than 25 years and specializes in the taxonomy of rodents. He also leads biodiversity projects and fauna surveys and his current concerns are for bats and their conservation. 